\title{
KONSERVASI MASIH MINORITAS
}

\author{
Franky Liauw* \\ Jurusan Arsitetur Fakultas Teknik Universitas Tarumanegara \\ *frankyl@ft.untar.ac.id
}

\begin{abstract}
ABSTRAK
Pihak yang pro konservasi masih minoritas. Konservasi dalam arti mempertahankan bangunan tua pada kondisi seperti semula menjadi barang aneh di tengah perubahan yang sangat pesat dalam hampir semua aspek kehidupan, di tengah persepsi bahwa perubahan dan perkembangan adalah tanda kemajuan. Konservasi hanya penting bagi minoritas ini. Bagaimana caranya membuat konservasi menjadi penting juga bagi mayoritas masyarakat? Mungkin ini adalah jalan keluarnya. Buktikan disertai fakta-fakta yang meyakinkan mengenai dampak negatifnya bila kita tidak mempertahankan warisan budaya bernilai tinggi bangsa kita, bila kita menghancurkan bangunanbangunan tua bersejarah yang menjadi identitas suatu kota, bila kita melupakan pengalaman dan nilai-nilai dari pendahulu kita, Buktikan juga bahwa konservasi tidak berarti mengurangi hak generasi mendatang dalam memenuhi kebutuhan mereka sesuai dengan perkembangan jamannya, bahwa konservasi tidak akan menjadi halangan bagi kebebasan generasi mendatang dalam menjalani kehidupannya, bahkan justeru sebaliknya, bahwa konservasi tidak akan merugikan pemilik bangunan bersangkutan, bahkan akan menguntungkan. Buktikan disertai perhitungan-perhitungan yang kuat bahwa konservasi justeru akan mendatangkan keuntungan bagi masyarakat dalam bidang ekonomi, bahkan akan meningkatkan mutu kehidupan masyarakat dan lingkungan hidup secara keseluruhan. Buktikan bahwa konservasi bukan berarti anti perubahan dan kemajuan, tapi dapat berjalan seiring dan justeru dapat menunjang kemajuan dan keseimbangan dalam kehidupan masyarakat, juga dengan perkembangan teknologi. Buktikan bahwa konservasi bukan hanya keinginan sekelompok elit tertentu untuk bernostalgia, tapi memang mewakili kepentingan kita semua. Buktikan bahwa konservasi tidak bersifat kaku dan hanya memaksakan kepentingan sepihak, tapi dapat dijalankan dengan fleksibel disesuaikan dengan kondisi dan perkembangan masyarakat. Buktikan bahwa masyarakat pelaku konservasi akan mendapat dukungan penuh karena tindakan ini bukan hanya bagi kepentingannya pribadi melainkan untuk kepentingan umum, bukan dipaksa atau malah menanggung semua beban biayanya sendiri. Masyarakat perlu diberikan bukti, bukan hanya kata-kata bujukan atau paksaan untuk melakukan konservasi. Masyarakat kita telanjur terlalu lama diberikan janji tanpa bukti. Bila persepsi terhadap konservasi dapat diubah, masyarakat banyak akan mendukung.
\end{abstract}

Kata kunci: konservasi, kepentingan dan dukungan masyarakat

\section{PENDAHULUAN}

Bicara mengenai konservasi adalah bicara mengenai kisah sedih. Banyak bangunan cagar budaya lenyap atau rusak, banyak bangunan bersejarah telantar, bahkan hancur dan hilang tanpa bekas. Pihak pembela konservasi masih jauh kalah kuat. Pihak yang pro konservasi masih minoritas.
Konservasi dalam arti mempertahankan bangunan tua pada kondisi seperti semula menjadi barang aneh di tengah perubahan yang sangat pesat dalam hampir semua aspek kehidupan, di tengah persepsi bahwa perubahan dan perkembangan adalah tanda kemajuan. Mempertahankan bangunan tua sementara banyak orang kekurangan tempat hunian, sementara pemiliknya ingin memenuhi kebutuhan yang sudah 
berbeda dan bertambah besar, sementara bahan bangunan lama sudah tidak diproduksi sehingga menjadi mahal, sementara gaya hidup dan budaya penduduk sekitarnya sudah berubah, dan banyak ketidaksesuaian lainnya, maka usaha ini menjadi sangat sulit karena menghadapi banyak tantangan. Konservasi yang bertahan tetap, kurang sesuai dengan karakter manusia yang cenderung terus berubah. Konservasi kelihatannya hanya penting bagi minoritas ini. Konservasi menjadi gerakan menentang arus yang sangat kuat. Perlu usaha besar dan strategi yang tepat agar dapat bertahan bahkan memperluas pendukung konservasi. Bagaimana caranya membuat konservasi menjadi penting juga bagi mayoritas masyarakat?

Sebenarnya konservasi sudah diangkat menjadi topik yang penting. Terbukti dengan dibuatnya dasar hukum tertinggi berupa Undang-undang Republik Indonesia Nomor 5 tahun 1992 tentang Benda Cagar Budaya. Pentingnya konservasi sudah banyak dikemukakan. Bangunan bersejarah yang dipertahankan dapat menjadi identitas kota, memiliki makna kultural dan merupakan warisan budaya, merupakan harta tak ternilai, kesinambungan masa lalu dengan masa kini dan masa datang, memiliki nilai sejarah yang penting bagi generasi sekarang untuk memahami keberadaannya.

Tingkat kepentingan konservasi sering terkurangi karena sebagian dari pihak pembuat undang-undang ini sendiri sering memberi ijin pembongkaran bangunan bersejarah, yang sudah dinyatakan dilindungi, dan menggantikannya dengan bangunan komersial. Nilai penting benda cagar budaya dikalahkan oleh nilai uang. Pihak yang kontra konservasi mendapat angin. Kebutuhan hidup dan pertimbangan ekonomi sering dikemukakan sebagai alasan.

Kurangnya dana juga sering diungkap sebagai alasan membiarkan bangunan bersejarah rusak. Pemilik bangunan bersejarah tidak selalu orang yang berduit atau mampu mengembangkan bisnis untuk membiaya bangunan miliknya. Di lain sisi, walaupun dinyatakan sebagai bangunan penting dan harus dilestarikan untuk kepentingan bangsa, beban biaya perawatan sering harus ditanggung pemiliknya sendiri. Oleh kebanyakan bangsa Indonesia, konservasi masih dianggap sebagai beban dan penghambat kemajuan.

Para ahli dan pembela konservasi harus dapat menjadikan konservasi sebagai kepentingan semua pihak, baik masyarakat maupun pemerintah. Harus dibentuk persepsi bahwa konservasi menguntungkan bagi semua pihak. Harus dibuktikan pula bahwa dengan memberdayakan bangunan cagar budaya, konservasi memang tidak lagi menjadi beban. Tidak bisa lagi kita hanya mengatakan kepada pemilik bangunan cagar budaya dan masyarakat bahwa bangunan tersebut penting dan harus dilestarikan, tapi mereka harus menanggung bebannya sendiri.

\section{PEMBAHASAN}

Kita semua mungkin pernah menyimpan dan merawat baik-baik benda yang "tidak ada harganya" 
seperti boneka kecil, foto yang sudah kuning lecek, atau benda lainnya yang membuat kita terkenang masa-masa indah dulu. Kenangan ini bisa sekedar nostalgia yang menyenangkan, tapi bisa juga mempunyai arti sangat penting bagi kehidupan seseorang, seperti mendatangkan harapan atau sebagai penjaga semangat hidup. Kehilangan bendabenda seperti ini sering menimbulkan kesedihan sangat mendalam.

Bangunan cagar budaya memiliki arti seperti itu, hanya jauh lebih penting karena merupakan benda milik sebuah bangsa. Bangunan cagar budaya bukan sekedar benda nostalgia, tapi memiliki nilai budaya yang menjadi kebanggaan nasional serta mencerminkan jati diri bangsa. Bangunan cagar budaya perlu dilestarikan untuk kepentingan sejarah bangsa, pengembangan ilmu pengetahuan dan kebudayaan serta banyak aspek lainnya yang dipercaya akan menentukan masa depan sebuah bangsa. Bangunan cagar budaya dapat menjadi alat belajar untuk memperbaiki apa yang sudah kita capai.

Sebagai milik bangsa, bangunan cagar budaya menyangkut kepentingan sebuah bangsa, kepentingan dalam skala besar. Tapi tepat di sini pula sumber masalahnya. Tidak semua orang dalam bangsa yang besar ini peduli akan pelestarian benda cagar budaya. Bahkan bukan sekedar tidak peduli, banyak yang melakukan tindakan perusakan dan penghancuran terhadap benda cagar budaya ini.
Ada dua kutub berlawanan yang sering membuat kegiatan konservasi tidak berjalan dengan lancar. Di satu sisi adalah pihak yang menganggap benda cagar budaya mempunyai nilai sejarah dan budaya penting dan harus dipertahankan, di sisi lain adalah pihak yang melihat lebih kuat dari aspek ekonomi dan kebutuhan saat ini. Mungkin perlu pertemuan antara keduanya.

\section{Persepsi terhadap bangunan cagar budaya}

Kalau kita membaca berita dan informasi mengenai bangunan cagar budaya di Indonesia, kebanyakan berisi cerita tentang penggusuran dan penghancuran bangunan tua yang akan digantikan dengan bangunan modern seperti pusat-pusat perbelanjaan, atau cerita mengenai bangunan kuno yang rusak dan hancur dengan sendirinya karena tidak dirawat, atau cerita mengenai pemerintah daerah yang memberi ijin kepada pengembang untuk membangun gedung baru menggantikan bangunan bersejarah, atau cerita mengenai pemilik bangunan tua yang kesulitan dana tapi diwajibkan oleh pemerintah untuk merenovasinya dengan biaya sendiri, atau cerita para ahli yang melontarkan kritik keras atas perusakan bangunan cagar budaya tapi tak berdaya mencegah pihak penguasa dan pemilik modal yang berposisi lebih kuat, atau cerita mengenai para ahli yang sama berusaha menekan para pengambil keputusan agar membatalkan rencananya membongkar bangunan kuno, atau cerita kota tua yang menjadi seperti kota hantu tak berpenghuni. 
Konservasi telanjur memiliki citra kurang berhasil. Banyak proyek konservasi yang gagal, baik dari segi bangunannya maupun dari sisi peningkatan mutu kehidupan masyarakatnya. Sangat berat, tapi harus diupayakan untuk mengubah persepsi seperti ini. Tanpanya, akan selalu terjadi penolakan terhadap langkah-langkah konservasi. Bangunan dan benda cagar budaya lainnya harus dicitrakan sebagai milik berharga bersama bangsa Indonesia, bahkan dunia, yang bila dijaga keutuhannya, di samping akan menjadi kebanggaan bangsa, juga akan menjadi modal usaha yang dapat menghidupi banyak orang dan meningkatkan taraf hidup masyarakat. Tidak logis bila kita menghancurkan modal usaha ini, tapi tidak masuk akal juga bila mempertahankannya persis seperti aslinya dulu kala.

Prinsip recycle dan reuse, pengembangan dan pemanfaatan kembali bangunan lama agar tetap mempunyai nilai guna, sangat sesuai dengan konsep keberkelanjutan kehidupan di bumi, yang sekarang ini menjadi arah langkah kita semua, sesuai pula dengan prinsip efisiensi yang menjadi jiwa dalam dunia ekonomi. Kita tidak selalu harus membongkar yang lama untuk membangun yang baru. Proses pertumbuhan yang harmonis dicirikan oleh hidup berdampingan antara yang yang tua dengan yang muda, seperti pada kehidupan manusia, begitu pula pada tempat tinggal manusia.

\section{Konservasi Menguntungkan Banyak Pihak}

Bangunan atau kawasan konservasi yang hidup akan menarik wisatawan lokal maupun mancanegara.
Wisata budaya berpotensi besar untuk dikembangkan dan menarik banyak wisatawan dalam dan luar negeri. Naik turunnya data jumlah wisatawan yang berkunjung ke Indonesia lebih disebabkan oleh isu keamanan. Wisata budaya yang berkembang akan menggerakan roda ekonomi dalam banyak sektor kehidupan.

Biro perjalanan dapat memasukkan bangunan atau kawasan konservasi tersebut sebagai salah satu obyek dalam paket wisata yang ditawarkannya. Untuk mempromosikannya akan terkait juga dengan percetakan, media cetak, dan media elektronik. Wisatawan yang menggunakan jasa biro perjalanan maupun melakukan perjalanan sendiri harus menggunakan alat transportasi, darat, mungkin udara, maupun laut. Wisatawan yang membutuhkan penginapan akan menghidupkan usaha perhotelan beserta seluruh karyawannya, atau penginapan di rumah-rumah penduduk. Semua wisatawan membutuhkan makanan, artinya giliran restoran yang mendapat bagian keuntungan. Mereka juga pasti akan menikmati jajanan pasar khas lokal. Sudah menjadi kebiasaan pula untuk membawa pulang cindera mata setempat, yang akan menghidupkan dan mengembangkan seni kerajinan tradisional.

Bagi pemerintah daerah, hidupnya roda perekonomian berarti meningkatnya pendapatan dari sektor pajak, berarti juga berkurangnya masalah bantuan yang harus diberikan pemerintah bagi penduduk miskin karena taraf hidup mereka sudah meningkat. Meningkatnya roda ekonomi akibat 
berkembangnya industri pariwisata sangat mungkin meningkatkan mutu kehidupan penduduk kawasan konservasi tersebut, bahkan lebih luas lagi mengingat sifat ekonomi yang tidak mengenal batas.

Mengingat keuntungan bagi banyak pihak lain dan pemerintah yang dipicu oleh konservasi, sudah sepantasnya sebagian keuntungan ini dikembalikan kepada kegiatan konservasi agar roda perekonomian tersebut dapat terus berputar. Mati atau hilangnya bangunan cagar budaya sebagai obyek wisata akan menghentikan kunjungan wisatawan, otomatis berdampak pada penurunan omzet usaha-usaha terkait yang diceritakan di muka. Konservasi harus dipandang sebagai modal usaha yang harus dipertahankan bersama-sama. Bila pemilik bangunan cagar budaya kesulitan dana untuk merenovasi atau merawat bangunan tersebut, perlu dibantu paling tidak di awalnya. Setelah mereka dapat menghidupi diri sendiri, baru bantuan tersebut dihentikan.

Obyek wisata yang banyak ragamnya, terdiri atas kumpulan bangunan dan benda cagar budaya dari berbagai periode, gaya, dan perjalanan sejarah, akan lebih menarik bagi para turis yang ingin berekreasi. Untuk itu selain pelestarian, bangunan dan benda cagar budaya perlu ditata agar menjadi "barang dagangan" yang laku dijual. Para ahli ekonomi dapat dimintai bantuannya untuk menghitung dengan lebih tepat berapa insentif yang pantas diberikan kepada para pelaku konservasi dari pajak yang dihasilkan. Kalaupun tidak dalam bentuk dana yang dianggarkan bagi perbaikan dan perawatan, insentif ini mungkin dapat berupa keringanan pajak bagi mereka, atau kemudahan-kemudahan bagi kegiatan-kegiatan yang terkait dengan proses konservasi, atau bantuan konsultan dan tukang ahli konservasi.

Disamping keuntungan ekonomi, pelestarian bangunan cagar budaya akan memberikan kekayaan dan keragaman wajah dan suasana kota, yang akan menciptakan keseimbangan dalam memenuhi kebutuhan hidup warga kota. Keragaman ini akan memberikan suasana tidak membosankan yang akan menjadi kenikmatan bagi warga kota. Kita semua akan dapat mempelajari sejarah kota langsung dari obyek sejarah aslinya, tidak hanya melihat gambar di buku pelajaran. UNESCO cukup menaruh perhatian terhadap kegiatan pelestarian benda cagar budaya, menganggapnya bukan hanya harta bangsa tertentu, tapi sebagai harta warisan dunia. Unesco dan badan dunia lainnya sebenarnya banyak yang bersedia membantu pendanaan pemeliharaan harta dunia tersebut.

\section{Belajar Dari Pengalaman Atau Sejarah}

Umat manusia dapat mencapai semua kemajuan sampai tingkat seperti sekarang, salah satunya adalah dengan cara belajar dari pengalaman masa lalu. Kita tentu tidak ingin selalu mengulang kesalahan masa lalu, walaupun kesalahan tersebut dilakukan oleh orang atau bangsa lain. Kita pasti selalu ingin peningkatan dari apa yang sudah dicapai oleh kita sendiri, ataupun apa yang sudah dicapai oleh orang atau bangsa lain. 
Bangunan cagar budaya merupakan kekayaan budaya bangsa yang penting artinya bagi pemahaman dan pengembangan sejarah, ilmu pengetahuan dan kebudayaan, sehingga perlu dilindungi dan dilestarikan demi memenuhi kebutuhan pengembangan budaya dan pengetahuan manusia. Benda cagar budaya mungkin dapat disamakan dengan buku atau bentuk dokumentasi lainnya. Mereka adalah rekaman dari apa yang sudah dicapai oleh manusia, mereka menyimpan ide-ide yang sudah pernah terpikirkan sehingga generasi kemudian dapat mengembangkan ide-ide lain yang berbeda dan lebih maju. Kita dapat belajar nilai-nilai positif yang terkandung dalam bangunan bersejarah ciptaan pendahulu kita. Bayangkan kalau semua buku atau bangunan bersejarah dimusnahkan.

Kumpulan bangunan bersejarah dapat merupakan urutan rekaman pembelajaran bangsa kita dalam bidang lingkungan binaan, akan menjadi pengingat bila kemudian kita melakukan kekeliruan dan kemunduran dalam perancangan bangunan di masa sekarang dan mendatang. Kumpulan bangunan bersejarah tersebut sebenarnya merupakan guru bagi para arsitek maupun kita semua.

Walaupun tidak sedinamis buku yang dengan mudah disebarkan ketempat lain yang jauh sekalipun, pada bangunan bersejarah kita dapat mengindera secara langsung serta mengalami suasana keruangan yang tidak mungkin dirasakan bila melihat gambarnya di buku. Selain itu dari bangunan bersejarah tersebut kita dapat mempelajari teknologi yang digunakan, dan kemudian mengembangkannya menjadi lebih baik. Bangunan bersejarah ini sebenarnya juga merupakan laboratorium hidup, tempat kita dapat mengamati interaksi bangunan dengan iklim setempat, bagaimana reaksi bangunan terhadap pengaruh lingkungan yang spesifik.

Tulisan menandakan mulainya sejarah, sebelumnya disebut sebagai masa prasejarah. Sejarah mencatat bahwa sejak manusia menemukan tulisan dan pendokumentasian, kebudayaan manusia mengalami perkembangan sangat pesat. Tanpa tulisan, alat komunikasi hanya berupa suara manusia yang daya jangkaunya sangat terbatas. Kemampuan mengingat juga sangat terbatas. Bahasa ucapan akan mudah terlupakan, tapi bahasa tulisan akan abadi. Begitu juga bangunan bersejarah yang bila hanya digambarkan tidak akan dapat menggantikan wujud nyatanya.

Bangunan bersejarah mengandung kisah peristiwa penting pada masa lalu yang terjadi di sana. Sama seperti buku yang merekam suatu peristiwa, bangunan bersejarah pun dapat selalu kita "baca" kembali untuk mengingatkan dan membuat kita belajar dari pengalaman penting bangsa dan pendahulu kita di masa lalu. Bangunan ini akan mengingatkan untuk menghindari peristiwa pahit yang terjadi pada masa lalu, atau mengingatkan kita pada kejadian yang dapat menjaga dan membangkitkan selalu kebanggaan dan semangat kita. Sebagai orang tua, kita tentu mengharapkan anak kita memberi perhatian, penghormatan, dan penghargaan yang sepantasnya kepada kita. Bila tidak kita akan menyebutnya kurang ajar. Begitu pula kita seharusnya 
terhadap orang tua kita, dan orang tua kita terhadap orang tuanya, dan seterusnya. Konservasi bangunan bersejarah merupakan salah satu wujud penghargaan kita kepada pendahulu kita, dan sebenarnya menunjukkan bahwa kita adalah orang yang pantas pula mendapat penghargaan dari anak cucu kita. Dan seterusnya.

\section{Konservasi Tidak Mengurangi Hak Generasi Mendatang}

Berdasar data tahun 2004 kepadatan penduduk Jakarta adalah 13240 orang per kilometer persegi, atau 13 orang per hektar. Apakah ini berarti setiap hektar lahan dan bangunan yang dikonservasi akan mengurangi hak 13 orang di kemudian hari untuk memanfaatkan lahan dan bangunan tersebut sesuai dengan keinginannya?

Menurut Undang-undang Nomor 5 tahun 1992, salah satu kriteria penetapan benda cagar budaya adalah berumur sekurang-kurangnya 50 tahun dan mempunyai nilai penting bagi sejarah, ilmu pengetahuan, dan kebudayaan. Merujuk kriteria ini, maka semakin lama akan semakin banyak jumlah benda cagar budaya, termasuk bangunan bersejarah yang harus dikonservasi, maka akan semakin banyak pula penduduk yang harus mengkompromikan keinginannya untuk "maju" dengan keharusan mempertahankan bangunan lama. Ini persepsi yang wajar muncul pada kebanyakan orang. Persepsi seperti ini yang berpotensi menimbulkan tindakan menentang kebijakan konservasi. Perlu dibuktikan bahwa konservasi tidak berarti mengurangi hak generasi mendatang dalam memenuhi kebutuhan mereka sesuai dengan perkembangan jamannya, bahwa konservasi tidak akan menjadi halangan bagi kebebasan generasi mendatang dalam menjalani kehidupannya, bahkan justeru sebaliknya, bahwa konservasi tidak akan merugikan pemilik bangunan bersangkutan, bahkan akan menguntungkan.

Mungkin banyak pemilik bangunan bersejarah merasa rugi memiliki bangunan tersebut karena mereka tak bisa berbuat apa-apa dengan bangunan itu. Padahal, bangunan tersebut bernilai ekonomis tinggi. Untuk kondisi-kondisi seperti ini, dan demi kepentingan yang lebih luas, pemerintah perlu turun tangan membantu. Banyak langkah kebijakan yang dapat dilakukan agar pemilik seperti ini tidak merasa dirugikan, malah bersedia berpartisipasi melestarikan bangunannya. Misalnya bantuan untuk mewujudkan keinginan pemilik bangunan tersebut dalam memberdayakan bangunannya, yang tentu saja harus sejalan dengan kepentingan kawasan yang lebih luas. Kepada pemilik mungkin diberikan pendampingan oleh ahli yang ditunjuk pemerintah agar berhasil dalam mewujudkan keinginannya.

Dari sisi aturan tata kota, misalnya mengenai ketinggian bangunan, mungkin juga diberlakukan secara fleksibel. Misalkan suatu bangunan konservasi berada dalam kawasan berketinggian bangunan maksimal 8 lantai, sedangkan ia sendiri hanya satu lantai, maka pemilik dapat mengalihkan atau menjual haknya kepada pemilik bangunan lain di dalam kawasan tersebut. Hal seperti ini sudah dilakukan juga 
di negara lain. Dengan demikian semua pihak mendapat manfaatnya. Pola yang sama dapat juga dilakukan terhadap KDB.

Sebenarnya hak generasi mendatang pula untuk tetap memiliki dan dapat menikmati bangunan bersejarah agar mereka dapat terus terhubung dengan nenek moyangnya, tetap memiliki ikatan dengan akarnya. Tugas kita adalah mengamankan secara berantai antargenerasi bangunan-bangunan yang mengandung nilai sejarah tinggi dan patut untuk menjadi bangunan cagar budaya. Pelestarian bangunan cagar budaya juga akan melengkapi kota dengan sarana rekreasi dan pendidikan.

Bangunan bersejarah yang dikonservasi perlu dilihat dalam rangkaian waktu yang berkelanjutan, tidak hanya mewakili satu generasi tertentu saja. Mungkin kita jauh lebih menghargai apa yang kita gunakan sekarang karena langsung dapat kita rasakan manfaatnya. Mungkin saja bangunan yang sekarang kita tinggali di masa datang akan menjadi bangunan yang masuk kategori harus dilestarikan. Mungkin suatu ketika di masa mendatang suatu kota akan dipenuhi oleh bangunan bersejarah yang semuanya harus dilestarikan. Namun percayalah pada masa itu akan ada penyelesaian yang tidak mengorbankan kepentingan generasi pada waktu itu. Nilai positif dari langkah melestarikan bangunan bersejarah yang diambil saat ini cukup memberi keyakinan bahwa ini adalah langkah yang benar. Saat inipun teknologi bangunan sudah mampu membuat bangunan setinggi hampir satu kilometer. Dengan kemampuan ini, tidak akan sulit mengatur perpaduan bangunan konservasi dengan bangunan modern masa kini dan masa mendatang. Suatu ketika mungkin saja akan tercipta kota bertingkat. Bagian bawah semuanya merupakan bangunan konservasi.

\section{Dukungan Bagi Pelaku Konservasi}

Kompas tanggal 24 Juni 2008 mengungkapkan bahwa 20 bangunan abad 19 dan 20 di kawasan wisata Kota Tua provinsi DKI Jakarta nyaris roboh. Pihak swasta pemilik bangunan-bangunan tersebut diminta segera melakukan perbaikan dan revitalisasi bangunan dengan biaya sendiri karena pemerintah provinsi DKI Jakarta tidak menganggarkan dana APBD untuk itu. Berita ini menunjukkan dengan jelas tidak adanya dukungan terhadap konservasi bangunan bersejarah dari pemerintah daerah.

Ketua Unit Pelaksana Teknis (UPT) Kota Tua menurut berita ini mengharapkan peraturan gubernur tentang master plan kota tua dipercepat pengesahannya agar pemanfaatan dan pengembangan kota tua dapat lebih cepat diatur. Pemprov DKI Jakarta berencana mengembangkan kota tua sebagai tujuan wisata sejarah yang atraktif.

Masih dalam berita ini, Kepala Subdinas Promosi, Dinas Kebudayaan dan Permuseuman menambahkan, bahwa jika Kota Tua dikembangkan secara maksimal dan profesional, kawasan wisata ini akan menjadi salah satu sumber pendapatan DKI Jakarta. Tapi tidak membantu mendanai. Beliau membandingkan dengan kota tua di dunia yang selalu ramai dikunjungi wisatawan mancanegara dan 
menjadi salah satu destinasi utama. Wisatawan yang datang kesebuah kota, umumnya ingin tahu perjalanan sejarah kota.

Pernyataan bahwa kawasan Kota Tua yang hidup akan menjadi salah satu sumber pendapatan DKI Jakarta perlu menjadi pegangan untuk mendukung pelestarian bangunan konservasi. Perhitungan para ahli ekonomi mengenai hal ini juga akan menguatkan.

Kondisi pemilik bangun konservasi bermacammacam. Mungkin ada yang mampu membiayai sendiri perbaikan dan perawatannya, ada juga yang tidak. Ada yang bisa memberdayakan menjadi tempat usaha yang menguntungkan, ada juga yang tidak. Yang tidak mampu perlu dibantu, yang mampupun layak mendapat bantuan dengan porsi berbeda mengingat hal ini terkait dengan kepentingan orang banyak yang lebih luas.

Buktikan bahwa masyarakat pelaku konservasi akan mendapat dukungan penuh karena tindakan ini bukan hanya bagi kepentingannya pribadi melainkan untuk kepentingan umum, bukan dipaksa memperbaiki dan merawatnya tapi harus menanggung semua beban biayanya sendiri. Bahkan sudah sepantasnya bila kepada pemilik bangunan cagar budaya yang merawat bangunan tersebut diberikan penghargaan, karena sebenarnya mereka telah berjasa bagi kepentingan orang banyak dan bangsa. Sebagai wakil yang mengatur kepentingan bangsa, pemerintah mungkin perlu mempertimbangkan bukan hanya aspek ekonomi dari benda cagar budaya, tapi tanggung jawab melestarikan benda budaya yang sering tak dapat diukur sekedar oleh aspek ekonomi.

\section{Prinsip bisnis dalam konservasi bangunan}

Butuh biaya besar untuk konservasi bangunan dan merawatnya. Pemerintah saat ini kelihatannya belum mampu membiayai seluruh kegiatan konservasi ini. Menyadari hal ini pemerintah membuka peluang bagi investor untuk berpartisipasi, menanam modalnya di bidang konservasi dan bisnis turisme. Hal ini paling tidak pernah dinyatakan oleh Kepala Dinas Pariwisata dan Kebudayaan Kota Cirebon, Moch. Hanafiah. Banyak contoh di berbagai negara yang memperlihatkan bahwa bisnis turisme cukup menguntungkan dan dapat hidup berkembang. Kepala Dinas Kebudayaan dan Permuseuman DKI Jakarta, Aurora Tambunan, juga menyatakan bahwa sudah ada beberapa pihak yang berminat menjadi pengelola eks gedung Imigrasi di Jalan Teuku Umar, Jakarta Pusat yang dijadikan tempat galeri lukisan.

Melihat keadaan di atas, sebenarnya peluang tercapainya pelestarian bangunan cagar budaya yang menjadi kepentingan pemerintah dan bangsa Indonesia, serta peluang memperoleh keuntungan dari bisnis turisme berbasis obyek bangunan dan kawasan cagar budaya, cukup terbuka lebar. Mungkin pihak pemerintah yang perlu memulai inisiatif mengajak para investor untuk duduk bersama ahli yang mewakili pemerintah dan bangsa, menghitunghitung seberapa besar investasi yang dibutuhkan, seberapa besar kemungkinan keuntungannya, seberapa besar kemudahan-kemudahan yang perlu 
diberikan oleh pemerintah kepada pihak investor, pada proyek konservasi ini ataupun pada bidang usaha lain dari investor tersebut.

Sudah lama konservasi dan pembangunan modern dianggap saling bertentangan. Sudah waktunya persepsi seperti ini dihapus. Pemerintah dan pengusaha dapat bekerja sama, mengkompromikan kepentingan bersama. Kriteria bangunan cagar budaya tetap terpenuhi, keuntungan bagi pengusaha tetap tercapai, dan masyarakat luaspun mendapat bagiannya. Pasti tidak kurang pula investor Indonesia yang memiliki semangat nasionalis, yang menganggap keterlibatannya dalam upaya pelestarian bangunan cagar budaya sebagai sumbangsihnya bagi bangsa dan negara. Hal ini tak dapat dipungkiri akan menjadi promosi yang efektif bagi usaha-usaha yang dijalankan oleh investor tersebut.

\section{Kemajuan yang seimbang}

Sebenarnya kita sering terjebak dalam anggapan "kemajuan" yang kita capai. Kita merasa maju bila dapat membangun gedung seperti yang ada di negara "maju". Kita merasa maju bila pembangunan kita meningkat pesat dalam waktu singkat. Kecepatan pembangunan sering sama dengan percepatan pengurasan sumber daya alam, bahkan sering diiringi dengan pelepasan bahan pencemar yang pesat dan berskala besar, yang saat ini dicurigai kuat sebagai penyebab pemanasan global.

Pola pembangunan yang sering kita lakukan adalah membabat bersih alam yang ada, dan menggantikan seluruhnya dengan lingkungan buatan yang sangat manusiawi, tapi kurang alami dan kurang bersahabat dengan lingkungan. Pola yang mirip sedang terjadi pula terhadap bangunan cagar budaya. Kalau pola pembangunan selama ini sudah terbukti menimbulkan dampak kerusakan terhadap lingkungan, maka pola perlakuan kita terhadap bangunan dan benda cagar budaya akan berakibat pada kerusakan budaya dan identitas diri bangsa. Wajah budaya kita akan sama seperti budaya bangsabangsa lainnya, sama seperti wajah kota-kota besar dunia yang serupa seragam tanpa identitas yang jelas.

Keberagaman dalam prinsip keseimbangan lingkungan hidup sebenarnya mirip dengan keberagaman dalam lingkungan binaan manusia. Sekarang pengembang berlomba menghijaukan kawasan untuk menyeimbangkan lingkungan buatan dengan alami, hal serupa perlu kita lakukan untuk keseimbangan bangunan baru modern dengan bangunan lama yang mempunyai nilai budaya, estetika, dan teknologi tinggi yang sepantasnya dipertahankan. Kriteria penentuan bangunan cagar budaya akan menjamin hanya bangunan-bangunan bermutu tinggi yang dilestarikan, bersanding dengan bangunan modern dengan mutu setara membentuk keseimbangan lingkungan buatan yang akan meningkatkan taraf hidup masyarakat.

\section{KESIMPULAN}

Bangunan cagar budaya adalah bagian dari kehidupan bangsa, tanpanya tidak akan lengkap. Ia juga bagian penting dari jaringan ekonomi turisme, bahkan 
sebenarnya merupakan modal penggerak utama. Kehilangan bangunan cagar budaya akan menurunkan tingkat perekonomian terutama di bidang pariwisata, dengan demikian menurunkan pendapatan bahkan mungkin menghilangkan pekerjaan banyak orang, dan menurunkan mutu kehidupan masyarakat, dan dengan demikian pula menurunkan pendapatan pemerintah. Jadi kepentingan kita semua untuk tetap melestarikan dan merawat serta memberdayakan bangunan cagar budaya agar memberi manfaat.

Tujuan konservasi adalah mempertahankan benda cagar budaya, tapi bukan hanya untuk konservasi semata, melainkan untuk meningkatkan mutu hidup masyarakat. Masyarakat perlu diberikan bukti, bukan hanya kata-kata bujukan atau paksaan untuk melakukan konservasi. Masyarakat kita telanjur terlalu lama diberikan janji tanpa bukti. Bila persepsi terhadap konservasi dapat diubah, masyarakat banyak akan mendukung.

\section{BACAAN}

Antariksa, 2007, Pelestarian Bangunan Kuno Sebagai Aset Sejarah Budaya Bangsa, Pidato Pengukuhan Jabatan Guru Besar dalam Bidang Ilmu Sejarah dan Pelestarian Arsitektur Pada Fakultas Teknik Universitas Brawijaya, Disampaikan pada Rapat Terbuka Senat Universitas Brawijaya Malang, 3 Desember 2007
Budihardjo, Eko, (Ed.), 1997, Preservation and Conservation of Cultural Heritage in Indonesia, Gadjah Mada University Press, Yogyakarta.

Day, Christopher, 2002, Spirit and Place, Elsevier, Amsterdam.

Department of the Environment and Heritage, Australian Government, 2004, Adaptive Reuse, Preserving Our Past, Building Our Future.

Jokilehto, Jukka, 2002, A History Of Architectural Conservation, Butterworth Heinemann, Oxford.

Low Setha, Dana Taplin, Suzanne Sheld, 2005, Rethinking Urban Park, The University of Texas Press, Austin.

Theobald, William F., ed., 2005, Global Tourism, third edition, Elsevier, Amsterdam.

Waluyo, Harry, International Measurement of the Economic and Social Importance of Culture, Ministry of Culture and Tourism RI. 